\title{
Investigations on carotenoids in lichens. XII. Some species from the Pyrenean Peninsula
}

\author{
BAZYLI CZECZUGA*. BLANCA CIFUeNTES ** \\ * Department of General Biology, Medical Academy, Kilińskiego 1, \\ 15-230 Białystok, Poland \\ ** Department of Plant Physiology, Complutense University, Madrid-3, Spain \\ (Received: August 22. 1985. Accepted: November 26. 1985)
}

\begin{abstract}
By means of column and thin-layer chromatography, the authors investigated the presence of various carotenoids in thalli of 12 species of lichens from the Pyrenean Peninsula. The following carotenoids were found: lycophyll, lycoxanthin, $\beta$-carotene, $\alpha-, \beta$-cryptoxanthin, lutein, lutein epoxide, zeaxanthin, antheraxanthin, canthaxanthin, phoenicoxanthin, adonixanthin, $\alpha$-doradexanthin, astaxanthin, diatoxanthin, neoxanthin, violaxanthin, mutatochrome, mutatoxanthin and rhodoxanthin. The total content of carotenoids ranged from 2.299 (Cetraria cucullata) to $39.402 \mathrm{mg} \cdot \mathrm{g}^{-1}$ dry weight (Pseudoevernia furfuraceae).
\end{abstract}

Key words: lichens, carotenoids

\section{INTRODUCTION}

During our investigations on the presence of carotenoids in lichens (Czeczuga 1979a, b, 1980b, c, 1985b) we found that some carotenoids are characteristic for species of certain genera. These investigations also showed that environmental factors have a marked effect on the total carotenoid content and on the presence of the various carotenoids in the species. It was with this in view that the present studies were undertaken to investigate the presence of carotenoids and their total content in the thalli of some lichen species growing in the Pyrenean Peninsula. The investigations were felt to be warranted since recently, increasing attention has been paid to carotenoids as pigments which can be of value in the taxonomy of plants. Such studies have been published on algae (Liaaen-Jensen 1977, Weber and Wettern 1980) and on fungi (Valadon 1976). It is therefore possible that the results of these investigations on various species of lichens may be applied in chemotaxonomy. 


\section{MATERIAL AND METHODS}

Twelve species of lichens belonging to 4 families were investigated (Table 1). They were collected from the Pyrenean Peninsula, Spain.

The thalli were cleaned of all organic debris, macerated, placed in dark bottles and covered with acetone. The air above the fluid in the bottle

Table 1

Investigated species of lichens

\begin{tabular}{|c|c|c|}
\hline Family and species & Collected from & Locality \\
\hline Stictaceae & & \\
\hline $\begin{array}{l}\text { Stica pulmonaceae Ach. } \\
\text { Lecanoraceae }\end{array}$ & Fagus sylvatica $\mathrm{L}$. & Madrid \\
\hline $\begin{array}{l}\text { Placodium teicholitum Ach. } \\
\text { Parmeliaceae }\end{array}$ & Pinus pinaster $\mathrm{L}$. & Madrid \\
\hline Cetraria cucullata Bell. & Land & Ciudad Real \\
\hline Parmelia borrei Turn. & Pinus pinaster $\mathrm{L}$. & Madrid \\
\hline Parmelia physodes Ach. & Pinus pinaster $\mathrm{L}$. & Madrid \\
\hline Platysma glaucum L. & Pinus pinaster $\mathrm{L}$. & Madrid \\
\hline Pseudoevernia furfuraceae Ach. & Querqus pirenaica Wit. & Segovia \\
\hline Usneaceae & & \\
\hline Evernia divaricata Ach. & Pinus pinaster $\mathrm{L}$. & Segovia \\
\hline Evernia prunastri Ach. & Querqus pirenaica Wit. & Segovia \\
\hline Ramalina farinaceae $\mathrm{L}$. & Querqus pirenaica Wit. & Segovia \\
\hline Ramalina scopolorum Dicks. & Querqus pirenaica Wit. & Segovia \\
\hline Usnea larıciana Vain. & Pinus pinaster $\mathrm{L}$. & Madrid \\
\hline
\end{tabular}

was changed to nitrogen to ensure an anaerobic atmosphere. The samples were kept in a refrigerator until used for chromatographic analysis of the carotenoid content.

The carotenoid pigments were extracted by means of $95 \%$ acetone in a dark room. Saponification was carried out by means of $10 \% \mathrm{KOH}$ in ethanol at a temperature of about $20^{\circ} \mathrm{C}$ for 24 hours in the dark in the nitrogen atmosphere.

Column and thin-layer chromatography, described in detail in our previous paper (Czeczuga 1980a) were used for separation of various carotenoids. A glass column (Quickfit-England) approximately $1 \mathrm{~cm}$ in diameter and 15-20 cm in length, filled with $\mathrm{Al}_{2} \mathrm{O}_{3}$ was used in column chromatography. The extract was passed through the column and the different fractions were eluted with the solvent. Silica gel was used for thin-layer chromatography with the appropriate solvent systems, the $\mathrm{R}_{f}$ values being determined for each spot. For identification of carotenoids, co-chromatography was employed with the use of standard carotenoids (Hoffman-La Roche and Co. Ltd. Basle, Switzerland and Sigma Chemical Company - USA). 
The pigments were identified by the following methods: a) behavoiur in column chromatography, b) absorption spectra of the pigments in various solvents recorded on a Beckman spectrophotometer model $2400 \mathrm{Du}, \mathrm{c}$ ) partition characteristics of the carotenoid between hexane and $95 \%$ methanol, d) comparision of $\mathrm{R}_{f}$ values in thin-layer chromatography, e) the presence of allylic hydroxyl groups determined by the acid-chloroform test, f) the epoxide test, and g) mass spectrum (Vetter et al. 1971).

Quantitative determinations of the concentrations of carotenoid solutions were made from the absorption spectra. These determinations were based on the extinction coefficient $\mathrm{E} 1 \% \mathrm{~cm}^{-1}$ at wavelengths of maximal absorbance in petroleum ether or hexane (Davies 1976).

\section{RESULTS}

The results of the chromatographic analysis of the lichen thalli are presented in Table 2 and Fig. 1. As can be seen from Table 3, 15

Table 2

List of the carotenoids from the investigated material

\begin{tabular}{|c|c|c|}
\hline Carotenoid & $\begin{array}{c}\text { Structure } \\
\text { (see Fig. 1) }\end{array}$ & Semisystematic name \\
\hline Lycoxanthin & $A-X-B$ & $\psi, \psi$-caroten-16-ol \\
\hline Lycophyll & $B-X-B$ & $\psi, \psi$-carotene-16,16'-diol \\
\hline$\beta$-Carotene & D-X-D & $\beta, \beta$-carotene \\
\hline$\alpha$-Cryptoxanthin & $\mathrm{C}-\mathrm{X}-\mathrm{F}$ & $\beta, \varepsilon$-caroten-3'-ol \\
\hline$\beta$-Cryptoxanthin & D-X-F & $\beta, \beta$-caroten-3-ol \\
\hline Canthaxanthin & G-X-G & $\beta, \beta$-carotene- $4,4^{\prime}$-dione \\
\hline Lutein & $\mathrm{E}-\mathrm{X}-\mathrm{F}$ & $\beta, \varepsilon$-carotene-3,3'-diol \\
\hline Lutein epoxide & E-X-I & 5,6-epoxy-5,6-dihydro- $\beta, \varepsilon$-carotene-3,3'-diol \\
\hline Zeaxanthin & $\mathrm{F}-\mathrm{X}-\mathrm{F}$ & $\beta, \beta$-carotene-3,3'-diol \\
\hline Antheraxanthin & $\mathrm{F}-\mathrm{X}-\mathrm{I}$ & 5,6-epoxy-5,6-dihydro- $\beta, \beta$-carotene-3,3'-diol \\
\hline Diatoxanthin & $F-Y_{1}-F$ & 7,8-didehydro- $\beta, \beta$-carotene-3,3'-diol \\
\hline$\alpha$-Doradexanthin & $\mathrm{E}-\mathrm{X}-\mathrm{H}$ & 3,3'-dihydroxy- $\beta, \varepsilon$-caroten-4-one \\
\hline Adonixanthin & $\mathrm{F}-\mathrm{X}-\mathrm{H}$ & 3,3 '-dihydroxy- $\beta, \beta$-caroten-4-one \\
\hline Phoenicoxanthin & $\mathrm{G}-\mathrm{X}-\mathrm{H}$ & 3-hydroxy- $\beta, \beta$-carotene-4,4'-dione \\
\hline Astaxanthin & $\mathrm{H}-\mathrm{X}-\mathrm{H}$ & $3,3^{\prime}$-dihydroxy- $\beta, \beta$-carotene-4,4'-dione \\
\hline Neoxanthin & I-Y-M & $\begin{array}{l}\text { 5,6'-epoxy-6,7-didehydro- } 5,6,5^{\prime}, 6 \text { '-tetrahydro- } \beta, \beta \text {-carote- } \\
\text { ne-3,5,3'-triol }\end{array}$ \\
\hline Violaxanthin & $\mathrm{I}-\mathrm{X}-\mathrm{I}$ & $\begin{array}{l}\text { 5,6,5',6'-diepoxy-5,6,5',6'-tetrahydro- } \beta, \beta \text {-carotene-3,3'- } \\
\text {-diol }\end{array}$ \\
\hline Mutatochrome & D-Y-K & 5,8-epoxy-5,8-dihydro- $\beta, \beta$-carotene \\
\hline Mutatoxanthin & F-Y-L & 5,8-epoxy-5,8-dihydro- $\beta, \beta$-carotene-3,3'-diol \\
\hline Rhodoxanthin & $\mathrm{N}-\mathrm{X}_{1}-\mathrm{N}$ & 4',5'-didehydro-4,5'-retro- $\beta, \beta$-carotene-3,3-dione \\
\hline
\end{tabular}


Table 3

The carotenoid composition of lichen species from the Parmeliaceae family $(\%$ of total carotenoids)

\begin{tabular}{|c|c|c|c|c|c|}
\hline Carotenoid & $\begin{array}{l}\text { P. furfu- } \\
\text { raceae }\end{array}$ & P. borrei & $\begin{array}{l}\text { P. physo- } \\
\text { des }\end{array}$ & $\begin{array}{l}\text { C. cucul- } \\
\text { lata }\end{array}$ & P. glaucum \\
\hline $\begin{array}{l}\beta \text {-Carotene } \\
\alpha \text {-Cryptoxanthin } \\
\beta \text {-Cryptoxanthin } \\
\text { Canthaxanthin } \\
\text { Lycophyll } \\
\text { Lycoxanthin } \\
\text { Lutein } \\
\text { Lutein epoxide } \\
\text { Zeaxanthin } \\
\text { Antheraxanthin } \\
\text { Phoenicoxanthin } \\
\text { Diatoxanthin } \\
\text { Neoxanthin } \\
\text { Astaxanthin } \\
\text { Mutatochrome }\end{array}$ & $\begin{array}{r}7.5 \\
2.4 \\
4.9 \\
25.2\end{array}$ & $\begin{array}{c}17.2 \\
\\
7.5 \\
\\
3.1 \\
2.6 \\
2.9\end{array}$ & $\begin{array}{r}37.3 \\
31.3 \\
4.3\end{array}$ & $\begin{array}{c}\text { trace } \\
9.5 \\
27.2\end{array}$ & $\begin{array}{r}7.1 \\
17.4 \\
14.0\end{array}$ \\
\hline $\begin{array}{l}\text { Total content, } \\
\text { mg } \cdot g^{-1} \text { dry wt. }\end{array}$ & 39.402 & 16.953 & 19.629 & 2.299 & 26.647 \\
\hline
\end{tabular}

Table 4

The carotenoid composition of lichen species from the Usneaceae family $\left({ }^{\circ}\right.$, of total carotenoids)

\begin{tabular}{|c|c|c|c|c|c|}
\hline Carotenoid & $\begin{array}{l}\text { E. diva- } \\
\text { ricata }\end{array}$ & $\begin{array}{l}\text { E. pru- } \\
\text { nastri }\end{array}$ & $\begin{array}{l}\text { R. farina- } \\
\text { ceae }\end{array}$ & $\begin{array}{l}\text { R. scopo- } \\
\text { lorum }\end{array}$ & $\begin{array}{l}\text { U. lari- } \\
\text { ciana }\end{array}$ \\
\hline $\begin{array}{l}\beta \text {-Carotene } \\
\alpha \text {-Cryptoxanthin } \\
\beta \text {-Cryptoxanthin } \\
\text { Canthaxanthin } \\
\text { Lycoxanthin } \\
\text { Lutein } \\
\text { Lutein epoxide } \\
\text { Zeaxanthin } \\
\text { Antheraxanthin } \\
\text { Phoenicoxanthin } \\
\text { Adonixanthin } \\
\text { Violaxanthin } \\
\alpha \text {-Doradexanthin } \\
\text { Astaxanthin } \\
\text { Mutatochrome } \\
\text { Mutatoxanthin }\end{array}$ & $\begin{array}{l}4.0 \\
2.8\end{array}$ & $\begin{array}{c}3.3 \\
\text { trace } \\
13.9 \\
3.5 \\
\\
\\
7.6 \\
24.7 \\
5.2\end{array}$ & $\begin{array}{r}12.4 \\
16.2 \\
39.6 \\
1.7 \\
26.9 \\
10.2\end{array}$ & $\begin{array}{l}5.5 \\
5.9\end{array}$ & $\begin{array}{r}32.5 \\
5.9 \\
14.4 \\
3.3\end{array}$ \\
\hline $\begin{array}{l}\text { Total content, } \\
\mathrm{mg} \cdot \mathrm{g}^{-1} \text { dry wt. }\end{array}$ & 9.564 & 14.230 & 11.871 & 21.358 & 5.740 \\
\hline
\end{tabular}


carotenoids were determined in the 5 species of lichens of the Parmeliaceae family. Of the 15 carotenoids found, $\beta$-cryptoxanthin, zeaxanthin and astaxanthin occurred in the thalli of all of the representatives of the Parmeliaceae studied. Another interesting finding was that of the presence of lycophyll

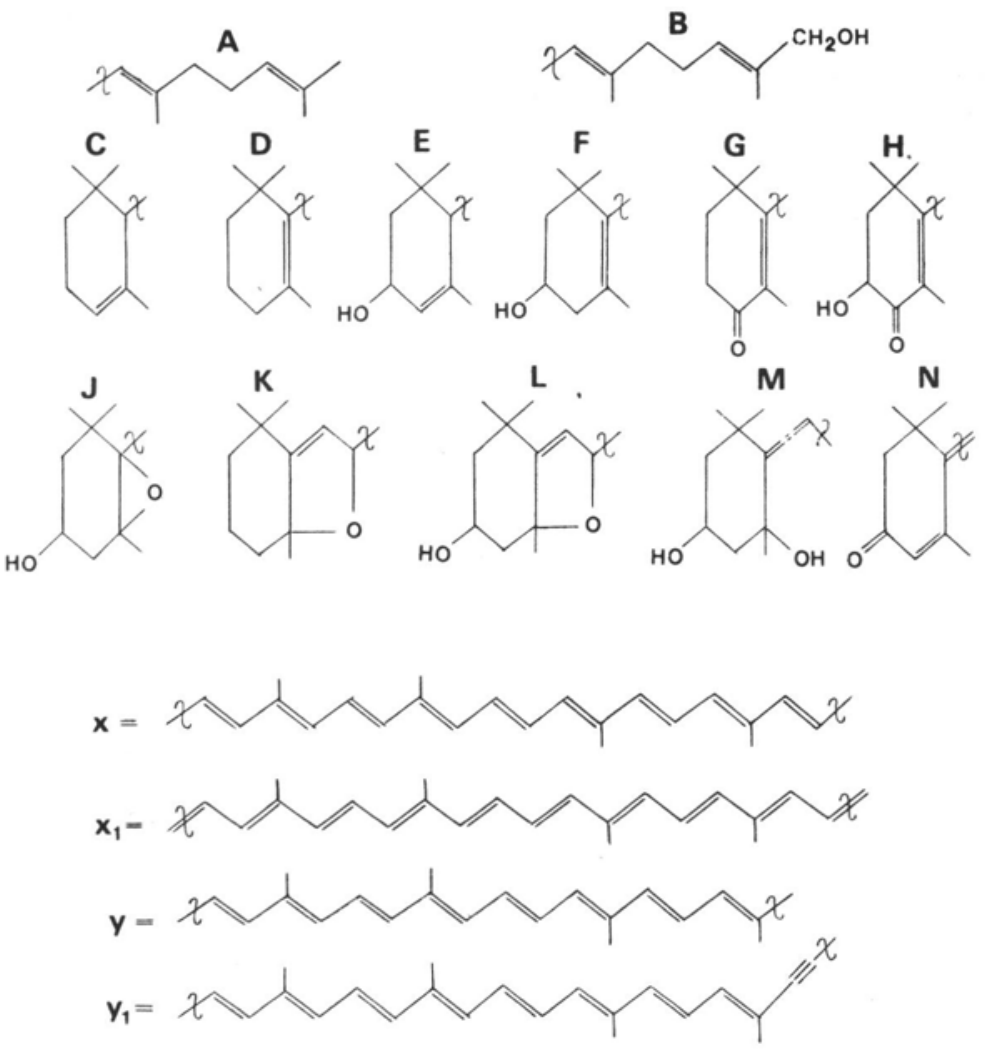

Fig. 1. Structural features of carotenoids from lichens

and diatoxanthin (Parmelia borrei), as well as lycoxanthin (Cetraria cucullata). The total carotenoid content in the representatives of this family ranged from 2.299 to $39.402 \mathrm{mg} \cdot \mathrm{g}^{-1}$ dry wt.

In the representatives of the Usneaceae family (Table 4), 16 carotenoids were determined of which $\beta$-cryptoxanthin and astaxanthin were found in all the Usneaceae species. The total carotenoid content of this material varied between $5.740 \mathrm{mg} \cdot \mathrm{g}^{-1}$ (Usnea laricina) and $21.358 \mathrm{mg} \cdot \mathrm{g}^{-1}$ of dry mass (Ramalina scopolorum).

In the representatives of the Stictaceae family (Table 5), 7 carotenoids were established of which lutein epoxide $(24.3 \%)$ and zeaxanthin $(23.9 \%)$ constituted the largest amounts. The total carotenoid content was 15.531 
Table 5

The carotenoid composition of lichen species from the Stictaceae and Lecanoraceae families ( $\%$ of total carotenoids)

\begin{tabular}{|l|c|c|}
\hline \multicolumn{1}{|c|}{ Carotenoid } & S. pulmonaceae & $P$. teicholitum \\
\hline$\beta$-Carotene & 17.3 & \\
$\beta$-Cryptoxanthin & 3.9 & 22.5 \\
Canthaxanthin & 2.4 & \\
Lutein & 8.7 & 5.4 \\
Lutein epoxide & 25.3 & 14.1 \\
Zeaxanthin & 23.9 & 43.1 \\
Rhodoxanthin & & 15.0 \\
Astaxanthin & 18.6 & 8.541 \\
\hline Total content. & 15.531 & \\
mg.g ${ }^{-1}$ dry wt. & & \\
\hline
\end{tabular}

$\mathrm{mg} \cdot \mathrm{g}^{-1}$ dry wt. In the representative of the Lecanoraceae family (Placodium teicholitum), 5 carotenoids were identified, their total content being 8.541 $\mathrm{mg} \cdot \mathrm{g}^{-1}$ dry wt. An interesting finding was that of rhodoxanthin which occurred in large amounts $(43.1 \%)$.

\section{DISCUSSION}

Of the carotenoids found in the species studied from the Pyrenean Peninsula, the most noteworthy are the 2 carotenoids of the acyclic group (lycophyll and lycoxanthin), 4 carotenoids of the ketocarotenoid group (phenicoxanthin, adonixanthin, $\alpha$-doradexanthin and rhodoxanthin) and one of the acetylenic group, diatoxanthin. The other carotenoids have been found in many other lichens (Czeczuga 1979a, b, 1980b, c, 1983, 1985b).

Lichens are composed of algae and fungi in symbiosis so that the carotenoids occurring in them are usually produced by the two symbionts. As regards the acyclic carotenoids found in the lichens studied, they appear to have been produced by the fungus component since such carotenoids have not been noted to date in algae (Wettern and Weber 1979). Only lycopene from which these two carotenoids are formed has been found in algae. These carotenoids have been found in some species of lichens from the Peltigera and Usnea families (Czeczuga 1979a, b). As for the carotenoids of the ketocarotenoid group, as phoenicoxanthin, adonixanthin and $\alpha$-doradexanthin, they are in the pathway of the conversion of $\beta$-carotene or some of its derivatives into astaxanthin (K a tayama et al. 1970). Adonixanthin has been found in plants, usually the higher plants. above all, in those of the Adonis genus (Egger 1965, Neamtu and Bodea 1968, Czygan 1969) and in the marine alga. Acetabularia mediter- 
ranea (K leinig and Egger 1967). Phoenicoxanthin is formed from canthaxanthin which has frequently been noted in algae (Czeczuga 1979c), fungi (Czeczuga 1980d) and lichens (Czeczuga 1985b). As regards $x$-doradexanthin, it is, according to Buchecker et al. (1978). formed from 3'-epilutein which has been described in plants as being a lutein isomer under the name of calthaxanthin (Dabbagh and Egger 1974). The presence of rhodoxanthin, in large amounts, in the thalli of Placodium teicholitum is noteworthy. This carotenoid, a derivative of zeaxanthin, has been found mainly in some representatives of mosses (Czeczuga 1985a) and the needles of coniferous trees (Ida 1981), although it has been found in the fungus Epicoccum nigrum (Foppen and Gribanovski-Sassu 1968). Diatoxanthin is also formed from zeaxanthin and has been found in algae of various families, among others, the Chlorophyceae (Liaaen-Jensen 1977, Czeczuga 1979c).

The total carotenoid content in the thalli of the studied species varied between $2.99 \mathrm{mg}$ and $39.402 \mathrm{mg} \cdot \mathrm{g}^{-1}$ dry wt., which in comparison with the data from other species, fall in the range of average values noted in other previously studied species (Czeczuga 1979a).

\section{REFERENCES}

Buchecker R.. Eugster C. H.. Weber A.. 1978. Absolute configuration of $\nsim$-doradexanthin and of fritschiellaxanthin. a new carotenoid from Fritschiella tuberosa Lyeng. Helvetica Chim. Acta 61: 1962-1968.

Czeczuga B., 1979a. Investigations on carotenoids in lichens. I. The presence of carotenoids in representatives of certain families. Nova Hedwigia 31: 337-347.

Czeczuga B., 1979b. Investigations on carotenoids in lichens. II. Members of the Usneaceae family. Nova Hedwigia 31: 359-356.

Czeczuga B., 1979c. Characteristic carotenoids in algae of different systematic position. Nova Hedwigia 31: 325-336.

Czeczuga B., 1980a. Investigations on carotenoids in Embryophyta. I. Bryophyta. The Bryologist (USA) 83: 21-28.

Czeczuga B., 1980b. Investigations on carotenoids in lichens. III. Species of Peltigera Willd. Cryptog. Bryol. Lichenol. 1: 189-196.

Czeczuga B., 1980c Investigations on carotenoids in lichens. IV. Representatives of the Parmeliaceae family. Nova Hedwigia 32: 105-111.

Czeczuga B., 1980d. Investigations on carotenoids in fungi. VIII. Members of Humariaceae. Nova Hedwigia 32: 355-360.

Czeczuga B., 1983. Investigations on carotenoids in lichens. VI. Mutatoxanthin, the dominant carotenoid in lichens of the Xanthoria genus. Biochem. Syst. Ecol. 11: 329-331.

Czeczuga B., 1985a. Investigations on carotenoids in Embryophyta III. Representatives of the Hepaticae. Phyton (Austria) 25: 113-121.

Czeczuga B.. 1985b. Investigations on carotenoids in lichens. VIII. Carotenoids in representatives of the Cladoniaceae. Biochem. Syst. Ecol. 13: 83-88.

Czygan F.-Ch.. 1969. Untersuchungen uber den Stoffwechsel der Ketocarotinoide in Adonis-Arten. I. Pigment-Zusammensetzung nicht normal gefarbter Blutenblatter. Planta (Berl.) 85: 35-41. 
Dabbagh A.G., Egger K., 1974. Caltaxanthin, the main pigment of Caltha palustris. isomeric to lutein. Z. Pflanzenphysiol. 72: 177-180.

Davies B. H. 1976. Carotenoids. In: Chemistry and biochemistry of plant pigments. Goodwin T. W. (ed.). Academic Press. London-New York-San Francisco. pp. 38-165.

Egger K., 1965. Die Ketocarotinoide in Adonis annua L. Phytochemistry. 4: 609-618.

Foppen F. H., Gribanovski-Sassu O., 1968. Lipids produced by Epicoccum nigrum in submerged culture. Biochem. J. 106: 97-100.

Ida K., 1981. Eco-physiological studies on the response of Taxodiaceous conifers to shading, with special references to the behavoiur of leaf pigments. I. Distribution of carotenoids in green and autumnal reddish brown leaves of Gymnosperms. Bot. Mag. Tokyo 94: 41-54.

Katayama T., Yokoyama H., Chichester C. O., 1970. The biosynthesis of astaxanthin. I. The structure of $\alpha$-doradexanthin and $\beta$-doradexanthin. Internat. J. Biochem. 1: 438-444.

Kleinig H., Egger K.. 1967. Ketocarotinoidester in Acetabularia mediterranea Lam. Phytochemistry 6: 601-619.

Liaaen-Jensen S., 1977. Algal carotenoid and chemosystematics. Marine Natur. Prod. Chem. 1: 239-259.

Neamtu G., Bodea C., 1968. Contributii la biosinteza carotinoidelor. I. Biogeneza carotinoidelor din Astragalus peterfii Jav. si Adonis aestivalis L. St. Cerc. Biochim. 11: 39-47.

Valadon L. R. G., 1976. Carotenoids as additional taxonomic characters in fungi: a review. ' Trans. Bryt. Mycol. Soc. 67: 1-15.

Vetter W., Englert G., Rigassi N., Schwieter U. 1971. Spectroscopic methods. In: Carotenoids. Isler O. (ed.). Birkhauser Verlag. Basel-Stuttgart. pp. 189-266.

Weber A., Wettern M., 1980. Some remarks on the usefulness of algal carotenoids as chematoxonomis markers. In: Pigments in plants. F.-Ch. Czygan (ed.). Gustav Fischer, Stuttgart-New York. pp. 104-116.

Wettern M., Weber A., 1979. Some remarks on algal carotenoids and their interconversion into animal carotenoids. In: Marine algae in pharmaceutical science. H. A. Hoppe, T. Levring and Y. Janaka (eds.), Walter de Gruyter, Berlin-New York. pp. 551-568.

\section{Badania karotenoidów u porostów. XII. Niektóre gatunki z pólwyspu Pirenejskiego}

\section{Streszczenie}

Stosując chromatografię kolumnową i cienkowarstwową badano występowanie poszczególnych karotenoidów w plechach 12 gatunków porostów z półwyspu Pireneiskiego. Ustalono występowanie następujących karotenoidów: likofil, likoksantyna, $\beta$-karoten, $\alpha$-, $\beta$-kryptoksantyna. luteina, epoksyd luteiny, zeaksantyna, anteraksantyna, kantaksantyna. feonikoksantyna, adoniksantyna, $\alpha$-doradeksantyna, astaksantyna, diatoksantyna, neoksantyna, wiolaksantyna, mutatochrom, mutatoksantyna oraz rodoksantyna. Ogólna zawartość karotenoidów wahała się od 2.299 (Cetraria cucullata) do $39.402 \mathrm{mg} \cdot \mathrm{g}^{-1}$ suchei masy (Pseudoevernia furfuraceae). 